\title{
Distribution and composition of macrozoobenthic communities along a Victoria-Land Transect (Ross Sea, Antarctica)
}

Received: 31 October 2005/ Revised: 24 January 2006/ Accepted: 24 January 2006/Published online: 24 February 2006 (C) Springer-Verlag 2006

\begin{abstract}
The Victoria-Land Transect project onboard the Italian research vessel "Italica" in February 2004, was a large-scale attempt to obtain benthic samples of smaller macrozoobenthic specimens systematically along a latitudinal and a depth transect along the VictoriaLand coast. Data presented from this survey are based on Rauschert dredge samples, which were taken at four areas at depth ranging from 84 to $515 \mathrm{~m}$. A cluster analysis based on relative numbers of abundance was performed and demonstrated a change in community structure depending on the location along the latitudinal transect. A change in community structure with depth was not recorded. Dominant taxa of the Ross Sea fauna along the Victoria-Land coast were the Arthropoda $(65.7 \%)$, followed by Annelida (20.7\%), Mollusca $(9.6 \%)$ and Echinodermata $(2.5 \%)$. Total number of abundance decreased with depth with an exception at Cape Russell, whereas a trend in biomass was not documented. Abundance and biomass proportions of major taxa changed gradually along the latitudinal transect.
\end{abstract}

\section{Introduction}

Numerous studies were performed to describe the benthos of high Antarctic shelf seas (e.g. Dearborn 1967;

P. Rehm $(\bowtie) \cdot$ W. E. Arntz · O. Heilmayer

Marine Animal Ecology, Alfred Wegener Institute for Polar and Marine Research (AWI), Am Alten Hafen 26,

27568 Bremerhaven, Germany

E-mail: prehm@awi-bremerhaven.de

\section{S. Thatje}

National Oceanography Centre,

Southampton, School of Ocean and Earth Science, University of Southampton, European Way,

SO14 3ZH Southampton, UK

\section{A. Brandt}

Zoologisches Institut und Museum, Universität Hamburg, Martin-Luther-King Platz 3, 20146 Hamburg, Germany
Dayton et al. 1970; Dayton and Oliver 1977; Dell 1990; Galerón et al. 1992; Gerdes et al. 1992; Arntz et al. 1994; Starmans et al. 1999), and one of the most striking characteristics, recorded of the benthos of the Antarctic shelf, is its richness in biomass and diversity (e.g. Hedgpeth 1969; Dell 1972; White 1984; Picken 1985; Dayton et al. 1994; Brey and Gerdes 1997). Particularly, the macrozoobenthic community structure of the southeastern Weddell Sea shelf is rather well known. Thus, three major benthic communities can be found in this area, which are characterized by suspension feeders, such as Porifera and Bryozoa, or mainly Bryozoa, or detritus feeders such as Holothurida and Polychaeta (Voß 1988; Gerdes et al. 1992; Gutt and Starmans 1998).

Most of the research characterizing habitats of the Ross Sea has been done around McMurdo Sound (Waterhouse 2001). Information about macrozoobenthic communities along the Victoria-Land coast (Ross Sea) is limited to only few restricted shallow water areas as Terra Nova Bay. Often previous sampling was centred on certain benthic groups such as Amphipoda, Mollusca, Polychaeta, and Porifera (e.g. Dayton 1972; Stockton 1984; Gambi et al. 1997; Knox and Cameron 1998; Cattaneo-Vietti et al. 1999; Cantone et al. 2000).

A first systematic classification of benthic communities of the southern Ross Sea was described from material obtained during the Trans-Antarctic Expedition from 1955-1958 and material collected by the New Zealand Oceanographic Institute. Bullivant (1967b) described 3 major benthic assemblages, which were linked to the substratum. The Deep Shelf Mixed Assemblage is characterized by Polychaeta, Bryozoa, Gorgonaria, and Echinodermata. Important elements of the Deep Shelf Mud Bottom Assemblage are Polychaeta and Echinodermata, whereas in the Pennell Bank Assemblage Bryozoa, Gorgonaria, Porifera, Tunicata, Cnidaria, and Echinodermata are common (Bullivant 1967b).

During the ROSSMIZE (Ross Sea Marginal Ice Zone Ecology) project carried out from RV "Italica" in 1994 and 1995, several macrobenthic samples were taken 
using a box-corer. While the sample areas were distributed in shallower waters along the Victoria-Land coast, only three stations in depths of 450,580 , and $810 \mathrm{~m}$ were sampled (Gambi and Bussotti 1999).

The cruise with RV "Italica", which was carried out in cooperation with the New Zealand RV "Tangaroa", was a large scale attempt to take samples systematically along a latitudinal and depth gradient. As there is little known about the ecosystem of the northern VictoriaLand coast, both the Italian research programme as well as the New Zealand Biodiversity Strategy programme "BioRoss" will essentially enhance our knowledge about biodiversity, structure, and composition of macrozoobenthic communities in the Ross Sea. The results shown in this paper represent some of the first analysed datasets from the study area.

\section{Materials and methods}

During the 19th Antarctic expedition of RV "Italica" to the Ross Sea in austral summer 2004, 18 dredge samples were taken along a latitudinal transect between Cape Adare and Terra Nova Bay. Sampling was performed in four areas: Cape Adare, Cape Hallett,
Coulman Island, and Cape Russell (Fig. 1; Table 1). As the sample station at Santa Maria Novella (Terra Nova Bay) is located nearby the Cape Russell area it is treated as part of this area and pooled for further analysis. Samples of area Cape Hallett were obtained from two depths transects inside and outside Cape Hallett Bay. At each area a slightly modified Rauschert dredge (Fig. 2, cf Lörz et al. 1999) with a mesh size of $500 \mu \mathrm{m}$ and an opening of $0.5 \mathrm{~m}$, was used to take samples from water depth between 84 and $515 \mathrm{~m}$. The dredge was trawled over the ground at a mean velocity of 1 knot. Haul lengths varied from 59 to $575 \mathrm{~m}$ (Table 1). As this type of dredge was specially designed to obtain small macrobenthic animals like peracarid crustaceans, an inner net with a mesh size of $1 \mathrm{~cm}$ was used to hold back larger objects to prevent the small dredge from being blocked too quickly. The material was sieved on a $500 \mu \mathrm{m}$ mesh, preserved in $90 \%$ precooled ethanol, and kept in $-25^{\circ} \mathrm{C}$ for later DNA extraction.

In the laboratory, samples were sorted into major taxonomic groups using a stereomicroscope. Biomass is given as ash free dry mass (AFDM) calculated from wet mass (WM) using conversion factors presented by Brey (2001).
Fig. 1 Victoria-Land coast (Ross Sea, Antarctica); sample areas: Cape Adare, Cape Hallett, Coulman Island, and Cape Russell, position of sampling marked with dots

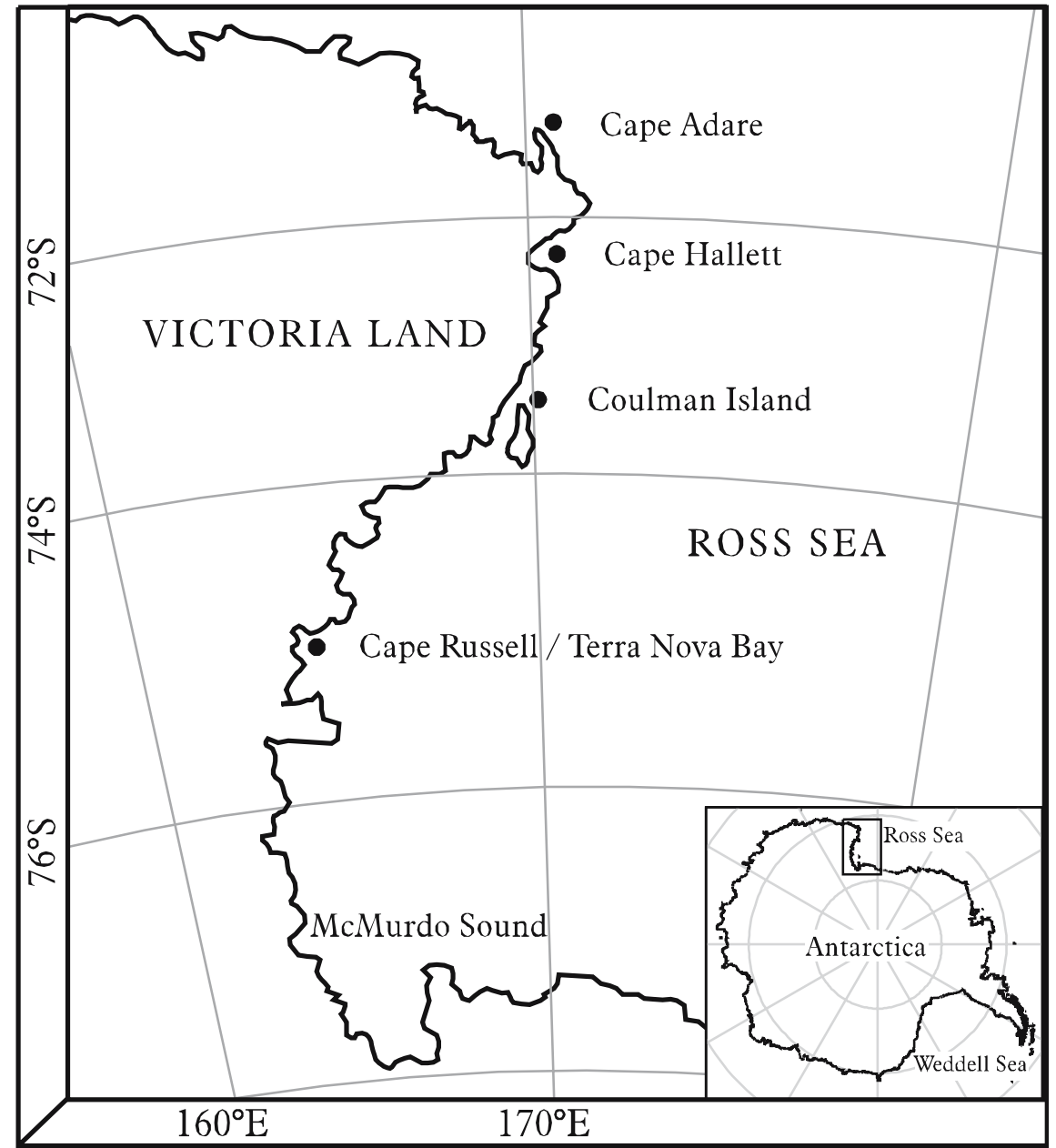


Table 1 Rauschert dredge stations of the Victoria-Land Transect Cruise, Ross Sea

\begin{tabular}{|c|c|c|c|c|c|c|}
\hline Station north to south & Date & \multicolumn{2}{|l|}{ Position } & Depth $[\mathrm{m}]$ & Haul length [m] & Sediment \\
\hline \multicolumn{7}{|l|}{ Cape Adare } \\
\hline A1 & $15 / 02 / 2004$ & $71^{\circ} 15.5^{\prime}$ & $170^{\circ} 41.9^{\prime}$ & 515 & 358 & sand with few pebbles and stones \\
\hline A2 & $14 / 02 / 2004$ & $71^{\circ} 17.3^{\prime}$ & $170^{\circ} 39.2^{\prime}$ & 421 & 298 & sand and gravel \\
\hline A3 & $14 / 02 / 2004$ & $71^{\circ} 18.7^{\prime}$ & $170^{\circ} 29.2^{\prime}$ & 305 & 257 & sand \\
\hline A4 & $14 / 02 / 2004$ & $71^{\circ} 18.4^{\prime}$ & $170^{\circ} 28.9^{\prime}$ & 230 & 376 & sand and pebbles \\
\hline H out 1 & $09 / 02 / 2004$ & $72^{\circ} 15.7^{\prime \prime}$ & $170^{\circ} 24.8^{\prime}$ & 458 & 375 & mud and pebbles \\
\hline H out 2 & $11 / 02 / 2004$ & $72^{\circ} 17.5^{\prime \prime}$ & $170^{\circ} 29.4^{\prime}$ & 353 & 375 & sandy mud and stones \\
\hline H out 4 & $12 / 02 / 2004$ & $72^{\circ} 18.5^{\prime \prime}$ & $170^{\circ} 26.8^{\prime}$ & 235 & 194 & sand \\
\hline $\mathrm{H}$ in 2 & $10 / 02 / 2004$ & $72^{\circ} 16.9^{\prime}$ & $170^{\circ} 12.2^{\prime}$ & 391 & 186 & coarse sand and small gravel \\
\hline $\mathrm{H}$ in 3 & $16 / 02 / 2004$ & $72^{\circ} 17.0^{\prime}$ & $170^{\circ} 13.1^{\prime}$ & 316 & 194 & muddy sand with stones \\
\hline $\mathrm{H}$ in 4 & $16 / 02 / 2004$ & $72^{\circ} 17.1^{\prime}$ & $170^{\circ} 14.0^{\prime}$ & 196 & 169 & mud and sand \\
\hline SMN & $20 / 02 / 2004$ & $74^{\circ} 43.2^{\prime}$ & $164^{\circ} 13.1^{\prime}$ & 366 & 192 & sand with gravel and stones \\
\hline $\mathrm{R} 2$ & $21 / 02 / 2004$ & $74^{\circ} 49.0^{\prime}$ & $164^{\circ} 18.1^{\prime}$ & 364 & 575 & fine sand \\
\hline R3 & $20 / 02 / 2004$ & $74^{\circ} 49.3^{\prime}$ & $164^{\circ} 11.5^{\prime}$ & 330 & 565 & rock, sand, mud and pebbles \\
\hline R4 & $20 / 02 / 2004$ & $74^{\circ} 49.3^{\prime}$ & $164^{\circ} 11.5^{\prime}$ & 208 & 97 & rock, mud and large stones \\
\hline
\end{tabular}

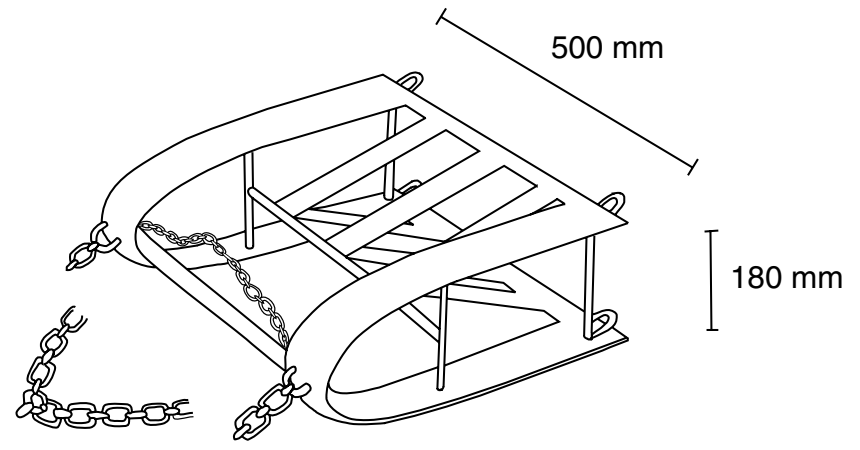

Fig. 2 Rauschert dredge, changed after Nickel (2003)

A cluster analysis was carried out with the programme Primer (v. 5.1.2) of the Plymouth Marine Laboratory (Clarke and Goreley 2000) using Bray-
Curtis-Index (Bray and Curtis 1957) and group average method. Because of the semi-quantitative nature of data from a dredge, relative numbers of abundance were used to calculate the analysis. As proper transformation for relative data, the function of arc sin was applied.

\section{Results}

A total of 27 taxonomic groups were identified from the area under investigation. The number of taxa varied between 14 and 27 with stations. In terms of abundance and biomass, the macrozoobenthic community of the Ross Sea shelf along the Victoria-Land coast collected with the Rauschert dredge was dominated by Arthropoda, followed by Annelida, Mollusca, and Echinodermata (Fig. 3). The Annelida were dominated by Polychaeta $(99.7 \%$ of total annelid abundance and
Fig. 3 Relative composition of major taxa from the Antarctic Ross Sea shelf off the VictoriaLand coast; a abundance, b biomass (AFDM)

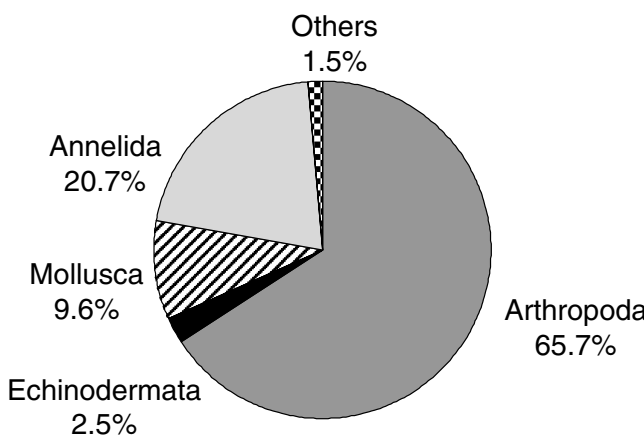

a

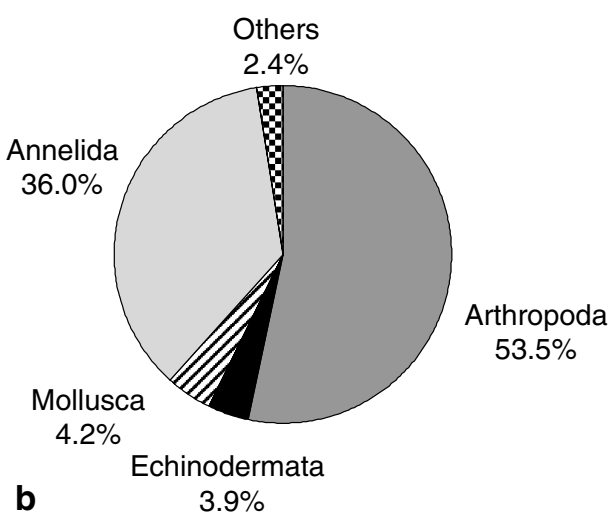


Fig. 4 Relative abundance of major macrozoobenthic taxa

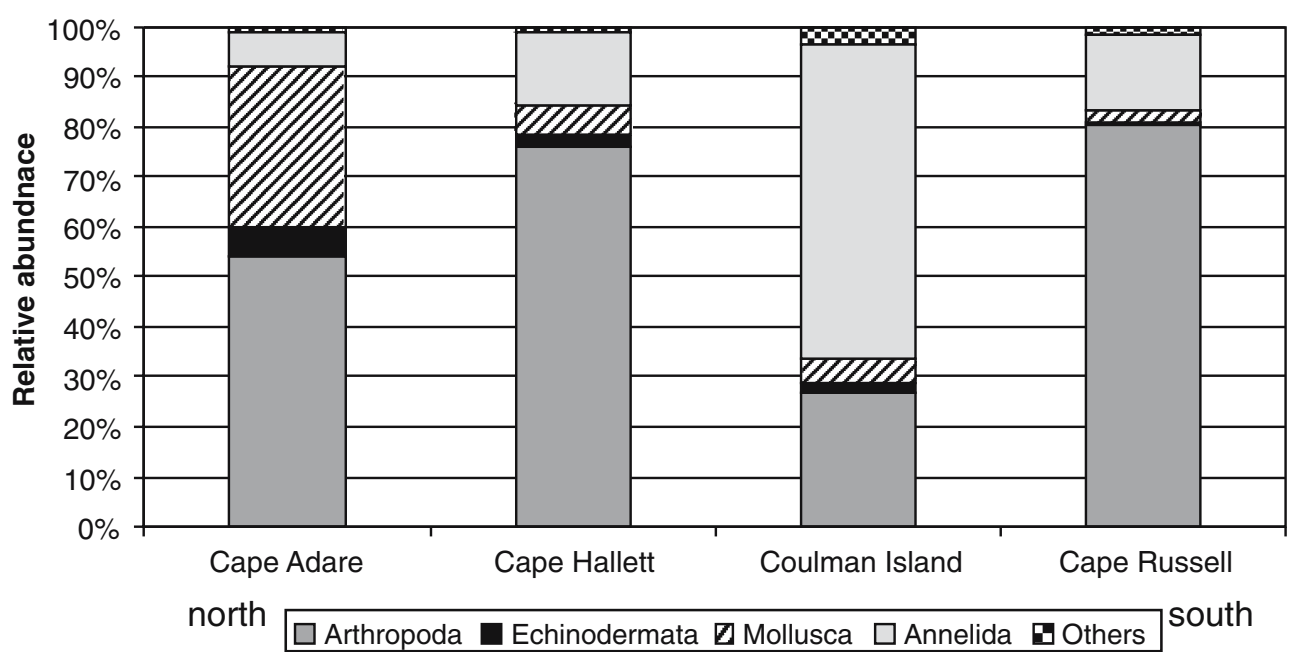

$100 \%$ of total annelid biomass); only few specimens of Hirudinea were found. Most Arthropoda belonged to the Crustacea (95.3\% of total abundance and $95.9 \%$ of total biomass). Further arthropod taxa, other than Crustacea, belonged to Pycnogonida and Acari.

Sampling areas of Coulman Island and Cape Adare differed in the distribution pattern of major benthic taxa when compared with the other areas. Most abundant taxon of the Coulman Island area was Annelida $(62.8 \%)$, whereas the community of Cape Adare is characterized by an increased proportion of Mollusca $(32.1 \%)$, which is attributed to an increase in Gastropoda (Fig. 4; Table 2) at stations A3 and A4 (Fig. 5). Again, in terms of biomass Annelida (58.9\%) showed an

Table 2 Relative abundance (\%) of macrozoobenthic taxa from investigated sub-areas of the Antarctic Ross Sea shelf

\begin{tabular}{|c|c|c|c|c|c|}
\hline & Cape Adare & Cape Hallett & Coulman Island & Cape Russell & Ross Sea total \\
\hline Arthropoda & 53.80 & 76.23 & 26.56 & 80.04 & 65.75 \\
\hline Acari & 3.33 & 0.65 & 0.00 & 0.93 & 0.98 \\
\hline Pycnogonida & 1.40 & 2.75 & 0.91 & 1.33 & 2.13 \\
\hline Amphipoda & 31.13 & 50.19 & 7.35 & 27.13 & 38.64 \\
\hline Cumacea & 0.18 & 2.12 & 1.51 & 29.07 & 4.34 \\
\hline Decapoda & 0.00 & 0.01 & 0.01 & 0.05 & 0.01 \\
\hline Isopoda & 12.47 & 16.77 & 8.34 & 14.31 & 14.61 \\
\hline Mysidacea & 0.21 & 0.02 & 0.03 & 0.66 & 0.11 \\
\hline Tanaidacea & 5.02 & 3.61 & 8.49 & 6.49 & 4.83 \\
\hline Unidentified & 0.06 & 0.11 & 0.00 & 0.08 & 0.08 \\
\hline Echinodermata & 6.11 & 1.99 & 2.03 & 0.78 & 2.50 \\
\hline Asteroidea & 0.19 & 0.09 & 0.07 & 0.05 & 0.10 \\
\hline Crinoidea & 0.05 & 0.03 & 0.03 & 0.00 & 0.03 \\
\hline Echinoidea & 0.05 & 0.03 & 0.04 & 0.04 & 0.04 \\
\hline Holothuroidea & 1.32 & 0.04 & 0.21 & 0.13 & 0.27 \\
\hline Ophiuroidea & 4.49 & 1.80 & 1.67 & 0.56 & 2.06 \\
\hline Mollusca & 32.13 & 6.13 & 5.12 & 2.69 & 9.56 \\
\hline Bivalvia & 1.19 & 0.89 & 3.31 & 0.58 & 1.32 \\
\hline Cephalopoda & 0.00 & 0.00 & 0.00 & $<0.01$ & $<0.01$ \\
\hline Gastropoda & 30.43 & 2.90 & 0.95 & 1.29 & 6.59 \\
\hline Polyplacophora & 0.00 & 0.02 & 0.00 & $<0.01$ & 0.01 \\
\hline Scaphopoda & 0.00 & 0.01 & 0.55 & $<0.01$ & 0.09 \\
\hline Aplacophora & 0.52 & 2.23 & 0.31 & 0.80 & 1.54 \\
\hline Annelida & 6.87 & 14.58 & 62.80 & 14.64 & 20.69 \\
\hline Hirudinea & 0.01 & 0.09 & 0.03 & 0.00 & 0.06 \\
\hline Polychaeta & 6.86 & 14.49 & 62.77 & 13.64 & 20.63 \\
\hline Others & 1.09 & 1.07 & 3.99 & 1.85 & 1.50 \\
\hline Brachiopoda & 0.06 & 0.05 & 0.20 & 0.03 & 0.07 \\
\hline Cnidaria & 0.04 & 0.01 & 0.00 & 0.00 & 0.01 \\
\hline Nemertini & 0.72 & 0.74 & 1.92 & 1.08 & 0.95 \\
\hline Plathelminthes & 0.04 & 0.14 & 0.00 & 0.06 & 0.10 \\
\hline Sipunculida & 0.23 & 0.12 & 1.27 & 0.68 & 0.36 \\
\hline Tunicata & $<0.01$ & 0.01 & 0.00 & 0.00 & $<0.01$ \\
\hline Mean abundance [ind. $\mathrm{m}^{-2}$ ] & 26 & 74 & 65 & 20 & 26 \\
\hline
\end{tabular}




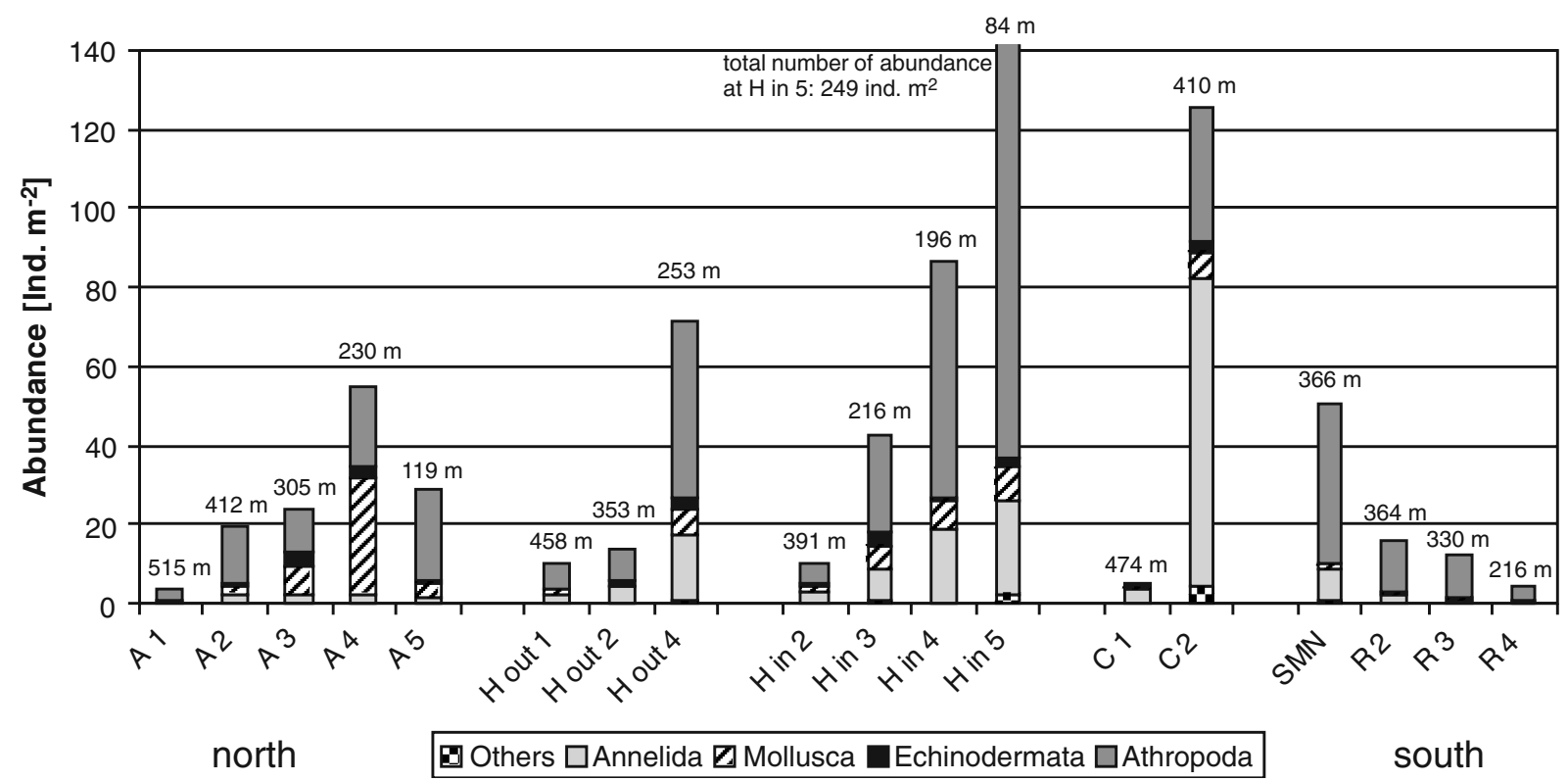

Fig. 5 Abundance of major taxa per Station (areas listed from north to south); $A$ (Cape Adare), $H$ out (Cape Hallett outer transect) $H$ in (Cape Hallett inner transect), C (Coulman Island), SMN (Santa Maria Novella), $R$ (Cape Russell)

exceptionally high portion at Coulman Island, but the biomass of Mollusca $(4.6 \%)$ was not increased at Cape Adare (Fig. 6; Table 3).

Taking into account an increased proportion of Annelida at Coulman Island, a trend of decreasing portions of abundance with latitude was found for Echinodermata, whereas portions of abundance of the Annelida showed the lowest numbers at the northern area Cape Adare. The portion of Arthropoda abundance increased, but biomass decreased with latitude (Tables 2, 3).

Cape Russell showed the lowest mean abundances (21 ind. $\mathrm{m}^{-2}$ ), whereas at Cape Hallett mean abundance was highest (75 ind. $\mathrm{m}^{-2}$, Table 4). Mean biomass value was lowest at Cape Russell and varied between $0.018 \mathrm{gm}^{-2}$ (AFDM) (Cape Russell) and $0.033 \mathrm{gm}^{-2}$ (AFDM) (Cape Hallett), (see Table 4).
The samples reflected a tendency of decreasing abundance with increasing depth (Table 5), with the only exception at Cape Russell where abundance increased with depth (Fig. 5). Biomass distribution displayed the same tendency, but both abundance and biomass numbers increased in the deepest samples from 400 to $515 \mathrm{~m}$ (Table 5).

The cluster analysis showed a separation of stations into six clusters (Fig. 7). Cluster C (similarity of about $40 \%$ ) contained the stations off Coulman Island, cluster $\mathrm{A}_{2}$ (similarity of about $50 \%$ ) combined stations $\mathrm{A} 3$ and A4. Again, stations off Coulman Island and stations A3 and A4 off Cape Adare differed from the other stations. Cluster R (similarity of about $60 \%$ ) contained the stations of Cape Russell with one exception: station R4 is located in the cluster $\mathrm{H}$ of Cape Hallett. The remaining clusters $A_{1}$ and $H$ are separated at about $65 \%$ similarity
Fig. 6 Relative biomass (AFDM) of major macrozoobenthic taxa

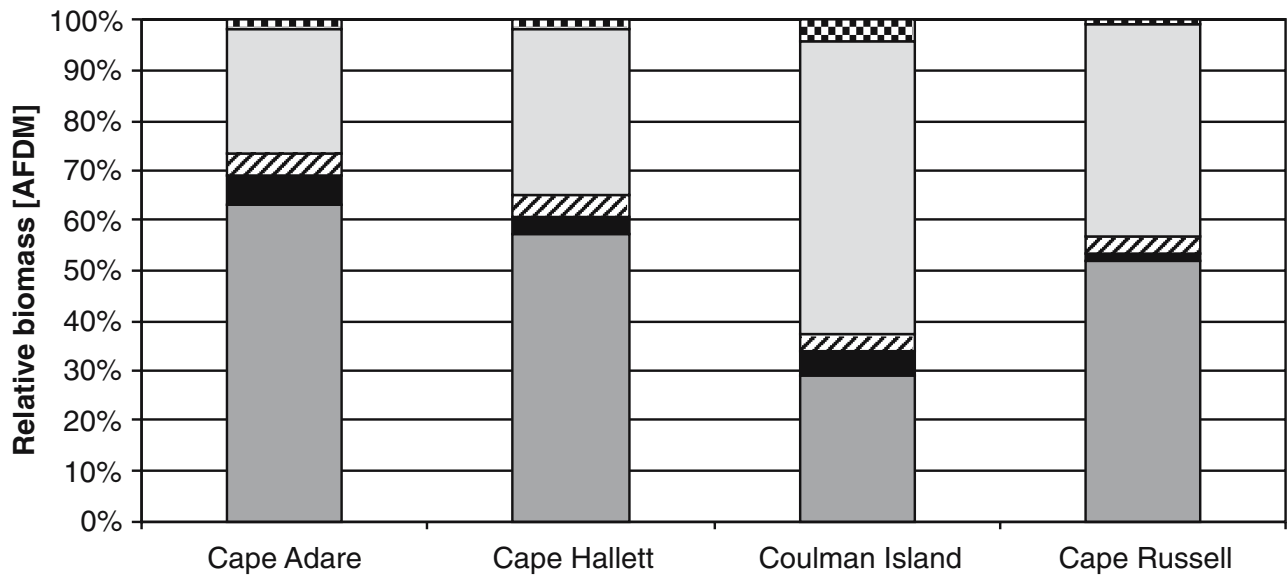

north $\square$ Arthropoda Echinodermata $\square$ Mollusca $\square$ Annelida $\mathbf{Q}$ Others south 
Table 3 Relative biomass (AFDM \%) of macrozoobenthic taxa from investigated sub-areas of the Antarctic Ross Sea shelf

\begin{tabular}{|c|c|c|c|c|c|}
\hline & Cape Adare & Cape Hallet & Coulman Island & Cape Russell & Ross Sea total \\
\hline Arthropoda & 63.34 & 57.08 & 29.13 & 51.85 & 53.76 \\
\hline Acari & 0.25 & 0.03 & 0.00 & $<0.01$ & 0.08 \\
\hline Amphipoda & 56.22 & 43.88 & 21.91 & 24.61 & 41.16 \\
\hline Cumacea & 1.22 & 1.47 & 2.30 & 10.82 & 2.72 \\
\hline Decapoda & 0.00 & 0.41 & 0.03 & 0.66 & 0.28 \\
\hline Isopoda & 3.40 & 4.72 & 3.20 & 14.22 & 5.38 \\
\hline Unidentified & $<0.01$ & 0.05 & 0.00 & 0.03 & 0.03 \\
\hline Echinodermata & 5.69 & 3.39 & 4.79 & 1.47 & 3.92 \\
\hline Asteroidea & 0.68 & 0.59 & 0.29 & 0.10 & 0.51 \\
\hline Crinoidea & 0.03 & 0.01 & 0.22 & 0.00 & 0.05 \\
\hline Echinoidea & 0.32 & 0.17 & 0.07 & 0.10 & 0.18 \\
\hline Holothuroidea & 0.46 & 0.70 & 2.60 & 1.01 & 0.97 \\
\hline Polyplacophora & 0.00 & 0.02 & 0.00 & 0.07 & 0.02 \\
\hline Scaphopoda & 0.00 & 0.02 & 0.13 & $<0.01$ & 0.03 \\
\hline Aplacophora & 0.22 & 0.57 & 0.10 & 0.12 & 0.36 \\
\hline Annelida & 24.88 & 33.24 & 58.90 & 42.15 & 36.17 \\
\hline Hirudinea & 0.00 & 0.01 & 0.02 & 0.00 & 0.01 \\
\hline Polychaeta & 24.88 & 33.23 & 58.88 & 42.15 & 36.17 \\
\hline Others & 1.50 & 1.73 & 3.95 & 1.02 & 1.92 \\
\hline Brachiopoda & 0.33 & 0.08 & 0.43 & 0.13 & 0.20 \\
\hline Cnidaria & 0.06 & 0.01 & 0.00 & 0.00 & 0.02 \\
\hline Nemertini & 0.98 & 1.18 & 3.30 & 0.35 & 1.34 \\
\hline Plathelminthes & 0.05 & 0.16 & 0.00 & $<0.01$ & 0.09 \\
\hline Sipunculida & 0.08 & 0.15 & 0.22 & 0.53 & 0.19 \\
\hline Tunicata & $<0.00$ & 0.14 & 0.00 & 0.00 & 0.07 \\
\hline
\end{tabular}

and comprise the stations of Cape Adare and Cape Hallett respectively. Merely station Hin5 is located within Cluster $\mathrm{A}_{1}$. As a general attribute, with respect to the exceptions mentioned above, stations are grouped according to their sample area.

Most characteristic for cluster C (Coulman Island) is the very high portion of Polychaeta (Table 3) and the lowest portion of Amphipoda and Isopoda. Cluster $\mathrm{A}_{2}$ as part of the area Cape Adare is characterized by reduced portions of Amphipoda, Tanaidacea, and Polychaeta, whereas Holothuroidea, Ophiuroidea, and especially Gastropoda show increased portions. Differences in between the remaining clusters are less distinct.
Cluster $\mathrm{R}$ showed the highest portions of Cumacea and low portions of Polychaeta. Within Cluster $\mathrm{A}_{1}$ Amphipoda were increased, whereas Isopoda and Cumacea were reduced. On the other hand, Tanaidacea showed a higher portion than in the other clusters.

\section{Discussion}

Selectivity of Rauschert dredge

A Rauschert dredge was used for sampling during the cruise with RV "Italica", which is known for its

Table 4 Benthos data of the investigated sub-areas of the Antarctic Ross Sea shelf

\begin{tabular}{llll}
\hline & Cape Adare & Cape Hallett & Coulman Island \\
\hline No. of stations & 5 & 7 & 2 \\
Depth range [m] & $119-515$ & $84-460$ & $410-474$ \\
Mean abundance [ind. m ${ }^{-2}$ ] & $26 \pm 17$ & $75 \pm 91$ & $65 \pm 60$ \\
Min-max abundance [ind. m $^{-2}$ ] & $3-55$ & $10-287$ & $5-125$ \\
Mean biomass [AFDM gm $^{-2}$ ] & $0.021 \pm 0.008$ & $0.033 \pm 0.040$ & $0.032 \pm 0.038$ \\
Min-max biomass [AFDM gm $^{-2}$ ] & $0.010-0.031$ & $0.004-0.108$ & $0.005-0.058$ \\
Mean biomass [WM gm $^{-2}$ ] & $0.199 \pm 0.232$ & $0.128 \pm 0.047$ & $0.178 \pm 0.217$ \\
Min-max biomass [WM gm $^{-2}$ ] & $0.068-0.177$ & $0.023-0.631$ & $0.024-0.332$ \\
\hline
\end{tabular}


Table 5 Depth distribution of macrozoobenthic abundance and biomass of the Antarctic Ross Sea shelf

\begin{tabular}{|c|c|c|c|c|c|c|c|}
\hline Depth & $\begin{array}{l}\text { No. of } \\
\text { stations }\end{array}$ & $\begin{array}{l}\text { Mean abundance } \\
\text { [ind. } \mathrm{m}^{-2} \text { ] }\end{array}$ & $\begin{array}{l}\text { Min-max abundance } \\
\text { [ind. } \mathrm{m}^{-2} \text { ] }\end{array}$ & $\begin{array}{l}\text { Mean biomass } \\
{\left[\text { AFDM m }{ }^{-2} \text { ] }\right.}\end{array}$ & $\begin{array}{l}\text { Min-max biomass } \\
{\left[\text { AFDM m}{ }^{-2}\right]}\end{array}$ & $\begin{array}{l}\text { Mean biomass } \\
{\left[\mathrm{WM} \mathrm{m}^{-2}\right]}\end{array}$ & $\begin{array}{l}\text { Min-max biomass } \\
{\left[\mathrm{WM} \mathrm{m}^{-2}\right]}\end{array}$ \\
\hline 84-200 m & 3 & 134 & $29-287$ & 0.043 & $0.005-0.108$ & 0.124 & $0.011-0.315$ \\
\hline $201-300 \mathrm{~m}$ & 3 & 44 & $5-72$ & 0.033 & $0.026-0.041$ & 0.103 & $0.082-0.129$ \\
\hline $301-400 \mathrm{~m}$ & 7 & 21 & $10-51$ & 0.015 & $0.006-0.031$ & 0.041 & $0.016-0.078$ \\
\hline $401-515 \mathrm{~m}$ & 5 & 33 & $3-125$ & 0.026 & $0.005-0.058$ & 0.075 & $0.012-0.166$ \\
\hline
\end{tabular}

effectiveness of catching smaller macrozoobenthic animals (especially peracrid crustaceans) compared to other sampling gear such as a Agassiz trawl (Lörz et al. 1999). Previous surveys to the Ross Sea were restricted to certain areas of the Victoria-Land coast or used wide-meshed nets for dragged gear only (e.g. Bullivant 1967a; Dayton et al. 1974; Gambi et al. 1997; Cattaneo-Vietti et al. 2000). For that reason only a minor part of the species from the Ross Sea fauna is recorded so far. The use of the Rauschert dredge substantially increased the numbers of recorded cumacean species from the Ross Sea known until now (to 290\%) and we expect to find similar situations for other peracarid crustaceans, which are known as a particularly speciose group of the Southern Ocean (DeBroyer and Jazdzewski 1996; Brandt 1999). One disadvantage of the dredge is its semi-quantitative sampling, making comparison with quantitative sampling gear, such as grabs, more difficult (Eleftheriou and Holme 1984; Rumohr 1990). Nevertheless, dragged gear qualifies for collecting samples from a vast surface compared to qualitative sampling gear, which lead to the deployment of dredges and trawls in preliminary studies to give primary insight into distribution and community structures (Arntz et al. 1996; Arnaud et al. 1998). Dragged gears are, in addition, particularly valuable to assess the species diversity of an area. The Rauschert dredge is equipped with a net to hold back all objects larger than $1 \mathrm{~cm}$, which otherwise would quickly block the net. This selective nature of the dredge explains differences to other studies carried out with other dredges, like Agassiz trawls. For that reason, our samples did contain only very few of Porifera, often these were only fractions; but we know from using other methods such as the SplashCam that Porifera are an important element of the communities in question. Porifera are typical of high Antarctic shelf communities and contribute an important amount, up to $47 \%$, to biomass in the Weddell Sea (Gerdes et al. 1992; Brey and Gerdes 1999). Further taxa, which were not recorded sufficiently, were Ascidiacea, Bryozoa, and Cnidaria these taxa are important in terms of biomass as well (Bullivant 1967b; Dayton et al. 1974, 1994; Voß 1988; Brey and Gerdes 1999), thus a comparison between the two areas has to be treated very carefully, considering different sampling gear. Ascidiacea, Bryozoa, and Porifera were excluded from this quantitative analysis, because of the irregular catches. As a consequence of the method, absolute numbers in biomass were lower than what we can expect for this area by comparison with other studies from the Weddell Sea (0.124-1,640 g wet weight) (Gerdes et al. 1992) and the
Fig. 7 Station dendrogram from the Cluster analysis; BreyCurtis-Index, group average method

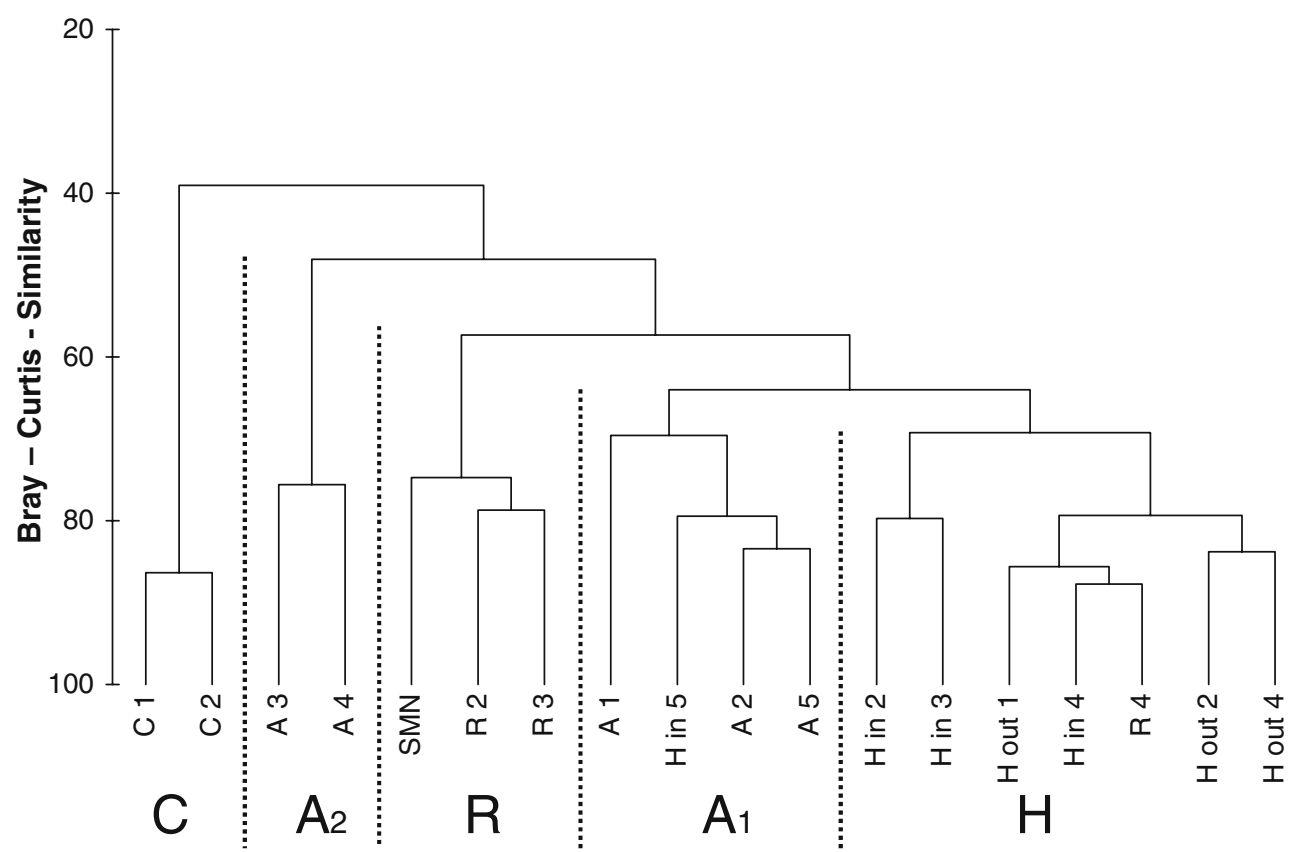


sub-Antarctic Magellan region $\left(0.01-22.88 \mathrm{gC} \mathrm{m}^{-2}\right)$ (Thatje and Mutschke 1999).

\section{Community structure}

The investigation of the macrozoobenthic community along a latitudinal transect was one of the main aims of the Victoria-Land Transect Cruise (Ramorino 2004). We were not able to identify all taxa to species level and thus in this paper we do only present preliminary data for the major 27 groups, which enable us to present an overall assessment of community structure. Species-level identification will be done by specialists for each taxonomic group; a future work that might take years to be completed. Data from this survey showed a gradual change in community composition of major macrozoobenthic taxa along a latitudinal cline. According to the cluster analyses, the structure of the community depended on the sample area.

Special situations were found for the community of Coulman Island and two of the stations (A3, A4) off Cape Adare. In the latter, the community was dominated by Polychaeta (62\%), and Gastropoda (47\%), respectively, instead of Arthropoda. The sediment of Cape Adare showed only slight variation and in contrast to abundance, biomass distribution of the deviating stations corresponded more with the remaining stations of the area. Thrush et al. (2004) recorded iceberg disturbance with a SplashCam for Cape Hallett and Cape Russell, and concluded that the iceberg disturbance regime was an important factor in determining community structure. Therefore the difference of the deviating stations appeared to be caused by iceberg disturbance. Unfortunately only two samples were taken at Coulman Island, thus deviation of community structure of this area might result from a disturbed area as well. However conditions at Coulman Island differed to that of the other areas, since the sediment mainly consisted of mud instead of sandy sediments, what could be an indication for a distinct community at Coulman Island. Furthermore, Bullivant (1967b) described the "Deep Shelf Mud Bottom Assemblage" dominated by polychaetes, which was found close to Coulman Island. In their quantitative analysis of the Ross Sea benthos in 1994 and 1995, Gambi and Bussotti (1999) excluded the very few colonial organisms (sponges, cnidarians, and bryozoans), which were found in the samples. From there a comparison of the two studies should be simplified, still the different gear used has to be taken into account. As the box-corer is predominantly samples infauna, one should expect more infaunal organisms in the samples from 1994 and 1995. During 1994 and 1995 the stations with muddy sediment were dominated by Polychaeta (58-78\%), whereas the station with sandy sediment was dominated by Crustacea (mainly Amphipoda) (50\%). This reflects similar differences found between the stations with different sediment types of this study.
The contrasting trends found in the change of proportion of arthropod abundance and biomass can be explained with changing proportions of arthropod taxa. The portion of Isopoda and Cumacea increases with latitude, whereas the portion of Amphipoda is low at the southernmost sample area Cape Russell. Amphipoda tend to be larger than Isopoda and Cumacea, and thus the biomass of Amphipoda is higher than that of Isopoda and Cumacea, hence a decreasing proportion of biomass despite an increasing portion of abundance of Arthropoda with latitude.

A tendency towards increasing density with decreasing latitude as it was found further to the south at the west coast of McMurdo Sound (Dayton and Oliver 1977) was not confirmed for the sample areas and therefore might be limited to McMurdo Sound. This result corresponds with the assumption that no distinct latitudinal gradient exists in organism density and biomass from the Magellan region to the high Antarctic (Gerdes and Montiel 1999; Piepenburg et al. 2002). The pattern of decreasing abundance coincided with decreasing depth, as known from several regions, such as the high Antarctic Weddell Sea and the sub-Antarctic Magellan Region (Brey and Gerdes 1998; Thatje and Mutschke 1999; Piepenburg et al. 2002).

Acknowledgements The authors are grateful to the crew of RV "Italica" for their help and their efficiency at sea, and express their sincere thanks to Prof. R. Cattaneo Vietti for the invitation to participate at and his support during the 19th expedition of the PNRA(S.C.r.1.). Dr. M. Chiantore was an inexhaustible source of information and aid during the organisation of the cruise and on board of RV "Italica". We are also grateful to Dr. S. Gatti for logistics planning and her help taking samples during the cruise. The German Science Foundation (DFG) provided travelling funds to the principal author $(\mathrm{Br} 1121 / 23-1)$.

\section{References}

Arnaud PM, López CM, Olasa I, Ramil F, Ramos-Éspla AA, Ramos A (1998) Semi-quantitative study of macrobenthic fauna in the region of the South Shetland Islands and the Antarctic Peninsula. Polar Biol 19:160-166

Arntz WE, Brey T, Gallardo VA (1994): Antarctic Zoobenthos. Oceanogr Mar Biol Annu Rev 32:241-304

Arntz WE, Gorny M, Lardies M, Mutschke E, Rios C (1996) Benthic macrofauna sampled with the Agassiz trawl. Ber Polarforsch 68:98-104

Brandt A (1999) On the origin and evolution of Antarctic Peracarida (Crustacea, Malacostraca). Sci Mar 63(Suppl 1):261274

Bray JR, Curtis JT (1957) An ordination of the upland forest of southern Wisconsin. Ecol Monogr 27:225-349

Brey T (2001) Population dynamics in benthic invertebrates. A virtual handbook. http://www.awi-bremerhaven.de/Benthic/ Ecosystem/FoodWeb/Handbook/main.html

Brey T, Gerdes D (1997) Is Antarctic benthic biomass really higher than elsewhere? Antarc Sci 9:266-267

Brey T, Gerdes D (1998) High Antarctic macrobenthic community production. J Exp Mar Biol Ecol 231:191-200

Brey T, Gerdes D (1999) Benthic community productivity in the Magellan region and in the Weddell Sea. Sci Mar 63(Suppl 1):145-148 
Bullivant JS (1967a) New Zealand Oceanographic Institute Ross Sea investigations, 1958-60: general account and station list. Bull NZ Dept Sci Ind Res 176:9-29

Bullivant JS (1967b) Ecology of the Ross Sea benthos. Bull NZ Dept Sci Ind Res 176:49-75

Cantone G, Castelli A, Gambi MC (2000) Benthic polychaetes off Terra Nova Bay and Ross Sea: species coposition, biogeography, and ecological Role. In: Faranda FM, Guglielmo L, Ianora A (eds) Ross Sea ecology. Italian Antarctic Expeditions (1986-1995). Springer, Berlin Heidelber New York, pp 551-561

Cattaneo-Vietti R, Chiantore M, Gambi MC, Albertelli G, Cormaci M, Di Geronimo I (1999) Spatial and vertical distribution of benthic litoral communities in Terra Nova Bay. In: Faranda FM, Guglielmo L, Ianora A (eds) Ross Sea ecology. Italian Antarctic Expeditions (1986-1995). Springer, Berlin Heidelberg New York, pp 503-514

Cattaneo-Vietti R, Chiantore M, Schiaparelli S, Albertelli G (2000) Shallow- and deep-water mollusc distribution at Terra Nova Bay (Ross Sea, Antarctica). Polar Biol 23:173-182

Clarke KR, Gorley RN (2000) Primer 5 for Windows, version 5.2.1. PRIMER-E Ltd

Dayton PK (1972) Toward an understanding of community resilience and the potential effects of enrichments to the benthos at McMurdo Sound, Antarctica. In: Parker BC (ed) Proceedings of the colloquium on conservation Problems in Antarctica. Lawrence, Kansas. Allen Press Inc. pp 81-96

Dayton PK, Robilliard GA, Paine RT (1970) Benthic faunal zonation as a result of anchor ice at McMurdo Sound, Antarctica. In: Holgate MW (eds) Antarctic ecology I. Academic, London, pp 244-258

Dayton PK, Robilliard GA, Paine RT, Dayton LB (1974) Biological accommodation in the benthic community at McMurdo Sound. Ecol Monogr 44:105-128

Dayton PK, Oliver JS (1977) Antarctic soft-bottom Benthos in Oligotrophic and Eutrophic environments. Science 179:55-78

Dayton PK, Mordida BJ, Bacon F (1994) Polar marine communities. Am Zool 34:90-99

Dearborn JH (1967) Stanford University invertebrate studies in the Ross Sea, 1958-61: general account and station list. The fauna of the Ross Sea. Bull NZ Dep Sci Ind Res 176:31-47

De Broyer C, Jazdzewski K (1996) Biodiversity of the Southern Ocean: towards a new synthesis for the Amphipoda (Crustacea). Boll Mus civ St nat Verona 20:547-568

Dell RK (1972) Antarctic benthos. Adv Mar Biol 10:1-216

Dell RK (1990) Antarctic Mollusca. With special reference to the fauna of the Red Sea. R Soc NZ Bull 27

Eleftheriou A, Holme NA (1984) Macrofauna techniques. In: Holme NA, McIntyre DA (eds) Methods for the study of marine benthos. IBP Hand Book 16. Blackwell Oxford pp 140216

Galerón J, Herman RL, Arnaud PM, Arntz WE, Hain S, Klages M (1992) Macrofaunal communities on the continental shelf and slope of the southeastern Weddell Sea, Antarctica. Polar Biol 12:283-290

Gambi MC, Castelli A, Guizzardi M (1997) Polychaete populations of the shallow soft bottoms off Terra Nova Bay (Ross Sea, Antarctica): Distribution, diversity and biomass. Polar Biol 17:199-210
Gambi MC, Bussotti S (1999) Composition, abundance and stratification of soft-bottom macrobenthos from selected areas of the Ross Sea shelf (Antarctica). Polar Biol 21:347-354

Gerdes D, Klages M, Arntz WE, Herman RL, Galéron J, Hain S (1992) Quantitative investigations on macrozoobenthos communities of the southeast Weddell Sea shelf based on multibox corer samples. Polar Biol 12:291-301

Gerdes D, Montiel A (1999) Distribution pattern of macrozoobenthos between the Magellan region and the Weddell Sea (Antarctica). Sci Mar 63(Suppl 1):149-154

Gutt J, Starmans A (1998) Structure and biodiversity of megaepibenthos in the Weddell and Lazarev Sea Antarctica: ecological role of physical parameters and biological interactions. Polar Biol 20:229-247

Hedgpeth JW (1969) Introduction to Antarctic zoogeography: In Antarctic map folio ser, Folio 11. Am Geogr Soc (Washington), pp 1-9

Knox GA, Cameron DB (1998) The marine fauna of the Ross Sea: Polychaeta. NIWA Biodiversity Mem 108, p 125

Lörz AN, di Renzo A, Nickel J (1999) Comparative analysis of three sampling gear types for marine macrobenthos. Ber Polarforsch 330:134-151

Picken GB (1985) Benthic research in Antarctica: past, present and future. In: Gray, Christiansen (eds) Marine biology of polar regions and effects of stress on marine organisms. Wiley, Chichester, pp 167-184

Piepenburg D, Schmid MK, Gerdes D (2002) The benthos off King George Island (South Shetland Islands, Antarctica): further evidence for a lack of a latitudinal biomass cline in the southern ocean. Polar Biol 25:146-158

Ramorino MC (2004) Rapporto sulla Campagna Antarctica Estate Australe 2003-2004 Diciannovesima Spedizione. Consorzio per lattuazione del programma Nazionale di Ricerche in Antartide, p 316

Rumohr H (1990) Soft bottom macrofauna: collection and treatment of samples. ICES Tech Mar Env Sci 8, p 18

Starmans A, Gutt J, Arntz WE (1999) Mega-epibenthic communities in Arctic and Antarctic shelf areas. Mar Biol 135:269-280

Stockton WL (1984) The biology and ecology of the epifaunal scallop Adamusium colbecki on the west side of McMurdo Sound, Antarctica. Mar Biol 78:171-178

Thatje S, Mutschke E (1999) Distribution of abundance, biomass, production and productivity of macrozoobenthos in the subAntarctic Magellan Province. Polar Biol 22:31-37

Thrush S, Funnel G, Cummings V, Budd R, Schwarz AM (2004) Inshore benthic ecology. In: Ramorino MC (ed) Rapporto sulla Campagna Antarctica Estate Australe 2003-2004 Diciannovesima Spedizione. Consorzio per lattuazione del programma Nazionale di Ricerche in Antartide, pp 242-245

Voß J (1988) Zoogeographie und Gemeinschaftsanalyse des Macrozoobenthos des Weddellmeeres (Antarktis). Ber Polarforsch 45:1-145

Waterhouse EJ (2001) Ross Sea region: a state of the environment report fort the Ross Sea region of Antarctica New Zealand Antarctic Institute, Christchurch, New Zealand

White MG (1984) Marine benthos. In: Laws RM (ed) Antarctic ecology, vol 2. Academic , London, pp 421-461 